\title{
Decolonising Geographical Knowledges
}

\section{Sarah A. Radcliffe}

\begin{abstract}
This piece provides an overview of decolonising approaches for geographers unfamiliar with the field, first by examining some of the ways in which decolonial scholarship seeks to build on - and go beyond - postcolonialism. Developing these points, it turns to discuss what it means to think about decolonising geography at this particular political, institutional and historical conjuncture, examining the urgencies and challenges associated in this moment particularly for British geography. The introductory intervention then moves to examine how the remaining intervention pieces understand and address the theme of decolonial scholarship and geography.
\end{abstract}

Key words postcolonial geography, decolonial, colonial-modernity, Indigenous theory, white supremacy, settler colonialism

\section{Beyond postcolonialism? Decolonial scholarship and concepts}

For Māori intellectual Linda Tuhiwai Smith, decolonisation refers to "a long-term process involving the bureaucratic, cultural, linguistic and psychological divesting of colonial power" (Tuhiwai Smith 2010: 33). Although the formal end of colonial rule resulted in the formation of postcolonial nation-states (formally sovereign states whose structures and modalities were conditioned by their colonial histories), the forms of knowledge - about economy, democracy, development, education, culture, racial-ethnic difference and so on - through which the world is apprehended and 
explained and modelled for the future are deeply rooted in post-Enlightenment EuroAmerican claims to be able to pronounce universal truths and to theorize the world (Mignolo 2000; Slater 2004). Consequently, power relations in the colonial present permeate all forms of knowing about and understanding the world. To postcolonial and decolonial scholars "knowledge production and everyday relations are informed by European colonial modalities of power and propped up by imperial geopolitics and economic arrangements" (Collard et al 2015: 323). Postcolonial geography has critiqued metropolitan schema in order to identify the longstanding legacies of colonialism in society and space, and ways of imagining and describing the world. Decolonial scholars build on postcolonial scholarship and examine ongoing sociospatial transformations not solely in relation to enduring Western influences, and rather seek theoretical-conceptual frameworks and political inspiration from anticolonial writers including WEB du Bois, Aimé Césaire, Frantz Fanon, Gloria Anzaldúa, LT Smith, as well as movements such as the '500 years of resistance', the World Social Forum, and the Zapatistas. Decolonial approaches emerge from, and engage with, a wide range of critical and radical scholarship including critical Black scholarship, Indigenous theory, feminist and queer theory (especially that informed by non-metropolitan concerns), and the modernity-coloniality-decoloniality (MCD) school (Asher 2013; Maldonado-Torres 2016). The decolonial option switches away from a postcolonial provincializing of Western claims. Instead, the decolonial turn encourages re-thinking the world from Latin America, from Africa, from Indigenous places, and from the marginalized academia in the global South, and so on (Grosfoguel 2011). Decolonial scholars argue that the modern episteme is always and intrinsically saturated with coloniality although it is insecure in its reach and depth (Rivera Cusicanqui et al 2016). In this sense, decolonial enquiry is not merely a 
concern of Indigenous people or Black populations; it is theirs and more, a broad call to understand and analyse the "universal rich with all that is particular.. the deepening and coexistence of all particulars" (Césaire, in Grosfoguel 2012: 45).

Geographers have of course had engaged, albeit through widely divergent lenses, with the universal and the particular for much of its disciplinary history. Its current interests in scale, global-local co-constitution, travelling knowledges, the spatialdiscursive-material dimensions of marginalization and exclusion all speak to the concerns of decolonial scholarship. Yet the MCD group provides the concept of colonial-modernity that works to re-frame and re-direct critical thinking about the universal and the particular. Colonial-modernity refers to the argument that modernity co-emerged with coloniality (colonial power), which consequently forms the underside of modernity (Mignolo 2000). Conjoining coloniality with modernity in this way shifts analytical attention to examine colonial power and the colonial present not as exceptional and situated 'elsewhere', but as integral to socio-spatial relations across multiple differentiated terrains and scales.

Within the context of colonial-modernity's sanctioned epistemicide of colonized subjects' knowledges (Santos 2016), decolonial writers also discern the existence of border or southern thinking that exists in social-spatial relations that have not been entirely defined by Euro-modernity. Decolonial scholars hence are alert to multiple, diverse epistemic and ethical projects. Knowledge production is thus understood to occur alongside and outside of the university, in large part enriched by South-South flows of knowledge (Fanon was read in Latin America from the 1960s for instance) and activist intellectuals. Yet this is not an either/or understanding of knowledge 
production - either in the university or beyond it. While decolonial thinking seeks to de-link from Euro-American frameworks it does so by acknowledging how western frameworks have often been vernacularized, resulting in original, critical "southern theory" (Connell 2007; Rivera Cusicanqui et al 2016).

Re-orientating intellectual work in this way generates sharp analytical insights into power -- including the abandonments and durabilities of imperial power -- remains alert to alternative articulations of/within power (Povinelli 2011; Grosfoguel 2012; Stoler 2016). These points find particular force in relation to decolonial approaches to racialization and knowledge production. Decolonial approaches consider Black and Indigenous experiences to be rooted in colonial-modernity, and ineluctably framed by white supremacy and racial categorisations. Following Fanon and Peruvian scholar Anibal Quijano, MCD scholars argue that the colonization of the Americas inaugurated colonial-modern divisions of labour, the racialization of non-Europeans, and intersectional hierarchies of race-gender-class and knowledge (Maldonado-Torres 2016; Lugones 2010). In this sense, "the tenets and the lingering histories of slavery and colonialism produced modernity as and with and through blackness" (McKittrick 2014: 17), while settler colonialism undercut Indigenous sovereignty (Razack 2002; Radcliffe 2017). As argued by critical race scholars in geography, racialization is integral to understanding knowledge production in the discipline which is majority white, resulting in insufficient attention being paid to racialization in geographical theory, practice and institutions (Kobayashi 2002; Pulido 2002). In parallel, decolonial writers seek to make visible white supremacy's material and epistemic consequences in order to disturb the "very system that cannot survive without antiblackness" and anti-indigeneity (McKittrick 2014: 17; Sium et al 2012), as in the 
activism of \#IdleNoMore). ${ }^{\mathrm{i}}$ Decolonial awareness of "the linkages between colonialism, racism and other forms of dehumanization" (Maldonado-Torres 2011: 2; also Mollett 2017) makes decolonisation an ethico-political as well as an analytical project.

How then to decolonise geographical knowledges where the tasks of radically rethinking and re-practicing knowledge production remain urgent (Wa Thiong'o 1986; Mignolo 2000)? For decolonial scholars, it is important to place diverse knowledges on a horizontal relation, bringing knowledges from different settings into juxtaposition with each other (Connell 2007). The varied "particulars" of the colonialmodern world hence engage diverse individuals and groups as theorizing, knowledgeable and critical interlocutors (Comaroff and Comaroff 2012). "Decolonizing knowledge necessitates shifting the geography of reason, which means opening reason beyond Eurocentric and provincial horizons, as well as producing knowledge beyond strict disciplinary impositions" (Maldonado-Torres 2011: 10; also 2016). When combined with (admittedly fragile and continuously worked on) decolonial political positionality, this geography of reason seeks for all interlocutors their facility with diverse epistemologies in order to generate "multiepistemic literacy" (Kuokkanen cited in Sundberg 2013: 34) in which (plural) border thinking adds to - not replaces -- diverse 'Western' knowledges (Grosfoguel 2012: 100; also Jackson 2014).

The ethical and political context for knowledge production remains fragile and contested however, not least when issues of Indigenous sovereignty are at stake. Comprising one strand in the broad field of decolonial thinking, Indigenous theory 
seeks to pinpoint the specificity of Indigenous disempowerment and to provide analytical and political alternatives to the Indigenous colonial present. This stance removes decolonial approaches from the realm of the metaphorical to examining the material and political costs of settler colonialism (Radcliffe 2017; Tuck and Yang 2012), and a scholarship defined neither by a "descriptive analytics of [anti-black or anti-Indigenous] violence.., a sigh of ... post-race relief, [nor a] dismal dance of authenticity" (McKittrick 2014: 25). Inspired by subaltern methodologies and feminisms of colour among others, decolonising geographical methodologies are sitting in plain sight, although the enactment and practice of decolonisation requires caution, guidance and humility, and is always complex and highly contentious.

Overall the "decolonial turn" builds on and extends postcolonial, feminist and critical race geography by centring the forms of knowledge production under colonialmodernity, in order to refine understandings of its particularities and to reanimate critiques of racialization, colonial-modern resource distributions, and epistemic violence. I have emphasized important - but often unacknowledged -- connections between critical geographical scholarship and decolonial perspectives, sketching out the ways some geographers have engaged with decolonising the discipline. However, decolonising geographical knowledges requires a broader commitment to decolonial agendas; the next section explores what it means to raise decolonial questions at the present time.

\section{Interventions and interlocutors}

Decolonising geography - as several contributors to this Thematic Intervention make clear - is not a comfortable process. British geography is characterised by its 
whiteness among academic staff and undergraduate students; decolonising geography socially and institutionally is hence an uphill struggle to confront and dismantle the "unbearable whiteness of geography" (Derickson 2016: 236). Although racism is generally more subtle in university spaces than other public spaces, they remain profoundly unequal racially. Academic geography is no exception: racism and colonial-modern epistemic privileging are often found in student selection and progress; course design, curriculum content; pedagogies; staff recruitment; resource allocation; and research priorities and debates. The call to decolonise geographical knowledges is occurring precisely at a moment when Britain's relations with the world are being increasingly driven by the resurgence of white supremacy across Anglophone contexts and post-imperial nostalgia (and the Empire 2.0 they legitimize) (Roy 2016), and when relations between the geographical discipline, security concerns (whether environmental or geopolitical) and policy imperatives are being rearticulated under colonial-modern frames. Hence the need to engage geographers as a whole in debates around decolonising the discipline. The Thematic Intervention pieces that follow address these issues in various ways.

One powerful way in which whiteness becomes unbearable in university-based disciplines is through the establishment and maintenance of a canon, a series of core thinkers whose works students have to read, incorporate and understand before moving onto 'recent' debates (Decolonizing the Curriculum 2016-17). Yet geography - at least in my experience - is less canon-fixated than other social sciences and humanities. Nevertheless as feminists, people of colour and queer geographers know all too well, there is hard work moving from research, to publications to getting material onto reading lists. British geography students still generally have few 
opportunities to engage with and learn from anti-colonial, Indigenous and decolonial scholarship (they also tend to lack the language skills to read non-English texts). What would it mean to incorporate more systematically - perhaps even canonize? -decolonial materials into our teaching? Would this unsettle both academic certainties and student presumptions in ways that could encourage multiepistemic fluency? As Daigle and Sundberg document below, a first year curriculum based on Indigenous scholars was profoundly discomfiting for predominantly white Canadian students, and its outcomes are as yet uncertain.

The prevailing political economy of knowledge production of white and neoliberal universities influences the actors, agendas and outputs of geography, a point first raised by postcolonial scholars. Decolonial scholars highlight how the embodiments, politics and economics of Anglophone academic production entrench power geometries of producing knowledge (Rivera Cusicanqui 2012; de Leeuw et al 2013). The neoliberalisation of universities worldwide increasingly requires "extraversion," that is the submission of southern, non-metropolitan and extra-university scholars to output-driven, Anglophone-oriented scholarship (Connell 2007). As a strategy to work outside and around such pressures, decolonial scholars advocate a process of 'entering and exiting academia' in order to encounter and engage critically with other knowledge-producing processes. This strategy is perhaps most feasible in contexts where civil society networks and vibrant histories of popular education facilitate such exchanges, as in the Colectivx Ch'ixi of Bolivia.

What does this imply for university-based, professional geographers in the UK? Decolonial approaches and path-breaking role-models around the world encourage us 
to engage more systematically in co-production of knowledge with decolonialinspired actors and institutions, beyond the academy. However whereas this might be a feasible option for established, tenured academics (such as myself) it risks taking younger, less established and untenured researchers into a territory unrecognised unrecognisable even - by the neoliberal academy. Thus the work of negotiating decolonial forms of 'impact', scholarship and partnership within the university is imperative. Moreover in order to ensure that decolonial theorising avoids becoming domesticated and retains its critical force entails that the university thinks carefully about the extent to which its interests and engagement reflect those of its surrounding communities (whether at local, national or international scales (Bogues, in Hale and Stephen 2013: 32).

What does it mean for the Royal Geographical Society to host a conference with the theme 'Decolonising Geographical Knowledges: Opening Geography to the World'? Undoubtedly, the history and geographies behind the conference speak to the colonial-modern resources and authority that continue to pervade British public life including some of its most respected institutions (cf. Legg 2017) -- and that have been concentrated and reproduced in the RGS-IBG itself. Yet if decolonising geographical knowledges also and necessarily - as argued by Jazeel (2017) - requires a disciplinewide engagement with the arguments, evidence and questions raised by decolonial and Indigenous thinking, then what better place to start than at the major British geography conference among its thousands of (international) participants? The call for 'decolonising geographical knowledges' remains polemical and rightly so, representing as it does a problem space for geography. 


\section{Introducing the interventions}

The pieces that follow pick up on and engage with the above introductory points in varied ways, reflecting in part the heterogeneous engagement with postcolonial and decolonial scholarship across the discipline, and in part individual positionalities in relation to decolonial thinking.

Jazeel (2017) identifies in decolonial thinking an opportunity for the discipline to engage with 'southern' knowledges in ways that challenge geography's colonial legacies under a broader responsibility to making knowledge differently. While voicing his fears that decolonial scholarship risks becoming a route to standard professionalization, he outlines the radical potential of producing knowledge beyond the discipline's international conferences and neoliberal universities. Such moves however necessitate the careful negotiation of methodologies, academic networks, project aims, and hard-earned research findings, so that geography does not perpetuate colonising moves. For instance under the rubric of the Anthropocene, geography's claims to 'global' significance are underlining specific processes of credentialization, professional boundary-marking, and turf-wars over funding, so too decolonial arguments raise crucial cautions.

In the second intervention, Daigle and Sundberg (2017) address another key area of geographical activity, namely teaching undergraduates. As noted above, geography in the UK is overwhelmingly white; in the western Canadian context they describe, First Nation claims and settler 'moves to innocence' inject other challenges to and possibilities for decolonial curricula and pedagogies. While acknowledging overlap with postcolonial, feminist, queer and critical race traditions, they identify two unique 
contributions from decolonial insights for teaching geography. First, teaching place is understood to be about accountability to Indigenous knowledge, and second, places are analysed as interconnected through the power geometries of global colonialmodernity. Although they speak from a context different to that of geographers in the UK and elsewhere, their search for curricular materials and pedagogies to engage reluctant white students offer important insights.

The following intervention by Noxolo (2017) addresses decolonial scholarship from a different perspective. She writes as a postcolonial geographer and associates decolonial agendas with Indigenous peoples and their political struggles over material concerns. Noxolo positions herself at odds with decolonial work, which she interprets as a personal-political positioning with insights that can be easily co-opted into colonial knowledge formations. Working from a postcolonial perspective, Noxolo critiques the material conditions for today's UK geography by analysing the Global Challenges Research Fund as a form of re-entrenching imperial and colonial security visions of the world, and metropolitan research practice. Legg's (2017) intervention also begins from a postcolonial analysis and offers two biographical moments as contexts within which he began to engage with thinking through the slow, difficult and ongoing process of decolonialism, namely challenging the practices that made colonies and sustain colonial-modernity. Together the pieces offer a wide-ranging and thoughtful engagements with some of the debates raised by the call to decolonise geographical knowledges.

Acknowledgements I wish to thank the contributors to the Themed Intervention, and Simon Naylor and the editors of the Transactions of Institute of British Geographers for their encouragement. 


\section{References}

Asher K 2013 Latin American decolonial thought, or making the subaltern speak. Geography Compass 7(12): 832-842.

Collard, R-C, Dempsey J and Sundberg J 2015 A manifesto for abundant futures. Annals of the AAG 105(2): 322-330.

Connell R 2007 Southern Theory. Cambridge, Polity.

Comaroff J and Comaroff J 2012 Theory from the South: or how Euro-America is evolving towards Africa. Boulder CO, Paradigm.

Daigle M and Sundberg J 2017 From where we stand: Unsettling geographical knowledge in the classroom. Transactions of the Institute of British Geographers this issue.

Decolonising the Curriculum 2016-17 Interdisciplinary seminar series Decolonising the curriculum in theory and practice. CRASSH, University of Cambridge.

de Leeuw, S. Greenwood, M and Lindsay, N. 2013 Troubling good intentions. Settler Colonial Studies 3(4): 381-394.

Derickson K 2017 Urban Geography II: Urban geography in the age of Ferguson. Progress in Human Geography 41(2) 230-244.

Grosfoguel R 2007 The epistemic decolonial turn: beyond political economic paradigms. Cultural Studies 21 (2-3): 211-223.

Grosfoguel R 2012 Decolonizing western uni-versalisms: Decolonial pluri-versalism from Aimé Césaire to the Zapatistas. Transmodernity 1(3): 88-104.

Hale, C. and Stephen, L. (eds.) 2013 Otros Saberes: Collaborative research on Indigenous and Afro-Descendant cultural politics. Santa Fe, School for Advanced Research Press. 
Jackson MS 2014 Composing postcolonial geographies: postconstructivism, ecology and overcoming ontologies of critique. Singapore Journal of Tropical Geography 35: 72-87.

Jazeel T 2017 Mainstreaming geography's decolonial imperative. Transactions of the Institute of British Geographers this issue

Johnson J, Cant G, Howitt R, \& Peters E 2007 Creating anticolonial geographies: embracing Indigenous knowledges and rights. Geographical Research 45(2): 117-120.

Kobayashi A 2002 The construction of geographical knowledge - racialization, spatialization, in K Anderson et al (eds.) Handbook of Cultural Geography. Blackwell. pp.544-556.

Legg S 2017 Decolonialism. Transactions of the Institute of British Geographers this issue.

Lugones M 2010 Toward a decolonial feminism. Hypatia 25(4): 742-759.

Maldonado-Torres N 2011 Thinking through the decolonial turn. Post-continental interventions in theory, philosophy, and critique - an introduction. Transmodernity 1(2): 1-15.

Maldonado-Torres N 2016 Outline of Ten Theses on Coloniality and Decoloniality. Franz Foundation online http://franzfanonfoundation, accessed 27 February 2017.

McKittrick K 2014 Mathematics black life. The Black Scholar: Journal of Black Studies and Research 44: 16-28.

Mignolo W 2000 Local histories/Global designs: coloniality, subaltern knowledges and border thinking. Princeton NJ, University of Princeton Press. 
Mollett S 2017 Irreconcilable Differences? A postcolonial intersectional reading of gender, development and Human Rights in Latin America. Gender, Place and Culture 24(1): 1-17.

Noxolo P 2017 Decolonial theory in a time of the re-colonisation of UK research. Transactions of the Institute of British Geographers this issue.

Povinelli E 2011 Economies of Abandonment. London, Duke University Press.

Pulido L 2002 Reflections on a white discipline. Professional Geographer 54(1): 4249.

Radcliffe SA 2017 Geography and Indigeneity I: Indigeneity, coloniality and knowledge. Progress in Human Geography 41: 220-9.

Razack S 2002 Race, Space and the Law: Unmapping a white settler society. Toronto, Between the Lines.

Rivera Cusicanqui S 2012 Ch'ixinakax utxiwa: A reflection on the practices and discourses of decolonization. South Atlantic Quarterly 111 (1): 95-109.

Rivera Cusicanqui S, Domingues J M, Escobar A, and Leff E 2016 Debate sobre el colonialismo intelectual y los dilemas de la teoría social latinoamericana. Cuestiones de Sociología 14 e009

Roy A 2016 Divesting from whiteness: the University in the age of Trumpism. Society and Space www.societyandspace.org 28 November 2016. Accessed 3 June 2017

Santos B 2016 Epistemologies of the South: justice against epistemicide. London, Routledge.

Sium A, Desai C \& Ritskes E 2012 Towards the ‘tangible unknown’: Decolonization and the Indigenous future. Decolonization: Indigeneity, education \& society 1(1): i-xiii. 
Slater D 2004 Geopolitics and the postcolonial: Rethinking North-South relations. Oxford, Blackwell.

Stoler A L 2016 Duress: Imperial durabilities for our times. London, Duke University Press.

Sundberg J 2013 Decolonizing posthumanist geographies. Cultural Geographies 21(1): 33-47.

Tuck E and Yang K W 2012 Decolonization is not a metaphor. Decolonization: Indigeneity, education \& society 1(1): 1-40.

Tuhiwai Smith L 2010 Decolonizing Methodologies. London, Zed Books.

Wa Thiong'o N 1986 Decolonising the Mind: the Politics of Language in African Literature. Heinemann Educational.

\section{Note}

\#Idle No More is a social movement which calls "on all people to join in a peaceful revolution, to honour Indigenous sovereignty, and to protect the land and water" (see http://www.idlenomore.ca/ accessed 3 June 2017). 